\title{
Recent advances in determining protein and amino acid requirements in humans
}

\author{
Rajavel Elango ${ }^{1,2}$, Ronald O. Ball ${ }^{3,4}$ and Paul B. Pencharz ${ }^{3,4,5,6 *}$ \\ ${ }^{1}$ Child E Family Research Institute, BC Children's Hospital, Vancouver, British Columbia, Canada \\ ${ }^{2}$ Department of Pediatrics, University of British Columbia, British Columbia, Canada \\ ${ }^{3}$ Department of Agricultural, Food and Nutritional Science, University of Alberta, Edmonton, Alberta, Canada \\ ${ }^{4}$ Department of Nutritional Sciences, University of Toronto, Ontario, Canada \\ ${ }^{5}$ Research Institute, The Hospital for Sick Children, Toronto, Ontario, Canada \\ ${ }^{6}$ Department of Paediatrics, University of Toronto, Ontario, Canada
}

(Submitted 30 August 2011 - Final revision received 7 March 2012 - Accepted 15 March 2012)

\section{Abstract}

During the past 25 years a significant amount of research has been conducted to determine amino acid requirements in humans. This is primarily due to advancements in the application of stable isotopes to examine amino acid requirements. The indicator amino acid oxidation (IAAO) method has emerged as a robust and minimally invasive technique to identify requirements. The IAAO method is based on the concept that when one indispensable dietary amino acid (IDAA) is deficient for protein synthesis, then the excess of all other IDAA, including the indicator amino acid, will be oxidized. With increasing intakes of the limiting amino acid, IAAO will decrease, reflecting increasing incorporation into protein. Once the requirement for the limiting amino acid is met there will be no further change in the indicator oxidation. The IAAO method has been systematically applied to determine most IDAA requirements in adults. The estimates are comparable to the values obtained using the more elaborate $24 \mathrm{~h}$-indicator amino acid oxidation and balance (24h-IAAO/IAAB) model. Due to its non-invasive nature the IAAO method has also been used to determine requirements for amino acids in neonates, children and in disease. The IAAO model has recently been applied to determine total protein requirements in humans. The IAAO method is rapid, reliable and has been used to determine amino acid requirements in different species, across the life cycle and in disease. The recent application of IAAO to determine protein requirements in humans is novel and has significant implications for dietary protein intake recommendations globally.

\section{Key words: Amino acid requirements: Protein requirements: Humans: Indicator amino acid oxidation: Stable isotopes}

The study of amino acid requirements in humans has been an active area of research for the past 25 years with the introduction of stable isotope based carbon oxidation methods ${ }^{(1,2)}$. This is a major advancement from earlier, when nitrogen balance was the primary method of choice to determine amino acid and protein requirements. The nitrogen balance technique has many limitations due to overestimation of nitrogen intake and an underestimation of nitrogen excretion. The net result leads to an overly positive balance and therefore underestimation of the requirement ${ }^{(1,2)}$. Furthermore, the nitrogen balance method requires adaptation of the body urea pool to the test amino acid intake and this usually takes up to $7 \mathrm{~d}^{(3)}$ and therefore is not always suitable for application in vulnerable populations, such as children. Other methods such as measurement of growth (infants), plasma concentrations of urea and amino acids have been used to determine protein/amino acid requirements, although they all have potential drawbacks and are relatively insensitive ${ }^{(1)}$. Methods based on carbon oxidation measured using stable isotopes have proven to be more rapid and sensitive to changes in amino acid intakes and have resulted in identification of requirement values much higher than those based on nitrogen balance. Details about the scientific debate on requirement estimates and various methods used to determine requirements have been published previously ${ }^{(4-8)}$.

During the recent Dietary Reference Intakes (DRI 2005) report and FAO report (in 2007) on protein and amino acid intake recommendations, requirement estimates for adult

Abbreviations: BCAA, branched chain amino acids; DRI, dietary reference intakes; EAR, estimated average requirement; IAAO, indicator amino acid oxidation; IAAB, indicator amino acid balance; IDAA, indispensable dietary amino acids; MSUD, maple syrup urine disease; PKU, phenylketonuria; RDA, recommended dietary allowance; TSAA, total sulphur amino acids; TPN, total parenteral nutrition. 
humans were based on a summary of studies conducted using carbon oxidation methods. Two methods were accepted as appropriate for the determination of amino acid requirements: the indicator amino acid oxidation method (IAAO), and the 24h-indicator amino acid oxidation and balance method (24h-IAAO/IAAB). Both methods involve feeding a range of test amino acid intakes and the measurement of a dose response in the oxidation of another amino acid (indicator amino acid), although the response pattern differs (Fig. 1). The major methodological difference between the two techniques lies in the length of adaptation period to the specific test amino acid intake and duration of the study day, with the IAAO technique being a short-term adapted fed state model. Full details are given later. Due to its minimally invasive approach, the IAAO model has been applied to determine almost all indispensable dietary amino acid (IDAA) requirements in adult humans, neonates, children and in several disease states. The following is a description and comparison of the IAAO and 24h-IAAO/IAAB methods; requirement estimates derived using the methods, and the application of the IAAO method in children, and during disease; and the recent application of the IAAO method to determine protein requirements.

\section{Methodological and data analysis considerations to determine amino acid and protein requirements}

To define amino acid or protein requirements it is necessary to measure a sensitive physiological variable in response to graded intakes of test amino acid or protein (Fig. 1). To make a more precise and statistically robust requirement estimate, it is also ideal to provide a range of test intakes from well below to above the expected mean requirement estimate. The range of test protein intakes allows the separation of the physiological variable into two distinct phases of a progressive increase or decrease until the requirement for the test amino acid is met, followed by a relative steady state (Fig. 1). The inflection point referred to as the 'breakpoint' can then be identified using two-phase linear regression cross-over analysis. This model selects the minimum residual standard error in a stepwise partitioning of data points

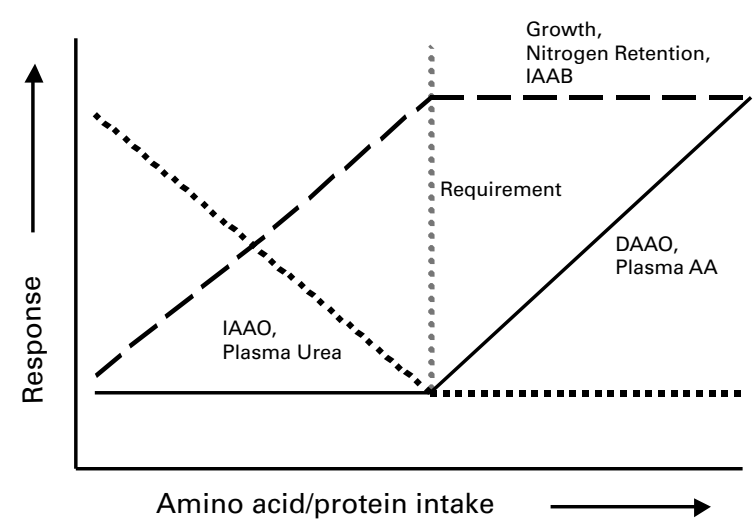

Fig. 1. Patterns of response observed due to increasing intake of limiting amino acid/protein intake. IAAO, indicator amino acid oxidation; DAAO, direct amino acid oxidation; IAAB, indicator amino acid balance; $A A$, amino acid $E A R$, estimated average requirement; RDA, recommended dietary allowance.

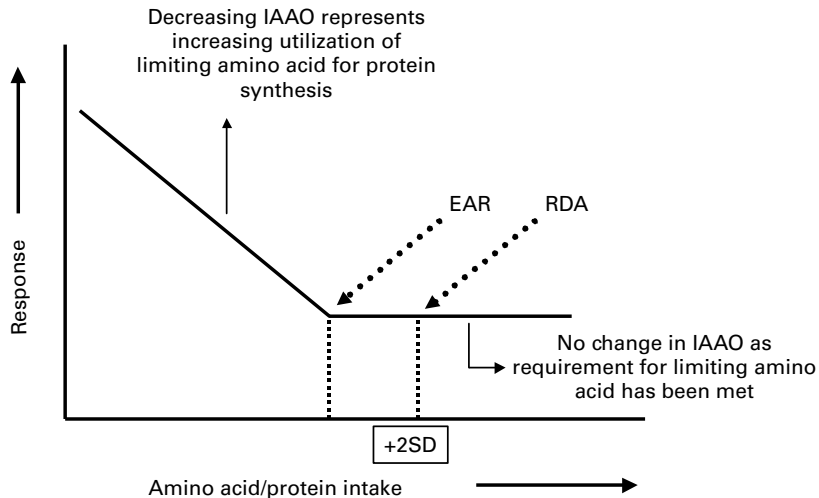

Fig. 2. Pattern of indicator amino acid oxidation (IAAO) observed due to increasing intake of limiting amino acid/protein intake. Indicator amino acid oxidation (IAAO): With increasing intake of the limiting amino acid, oxidation of the indicator amino acid will decrease, reflecting increasing incorporation into protein. Once the requirement is met for the limiting amino acid, there will be no further change in the oxidation of the indicator amino acid. The inflection point is referred to as the 'breakpoint' or requirement. The breakpoint identified with the use of bi-phase linear regression analysis indicates the mean or EAR of the limiting (test) amino acid. The upper $95 \%$ confidence interval calculated using Fieller's Theorem represents the population-safe requirement estimate or RDA. EAR, estimated average requirement; RDA, recommended dietary intake; SD, standard deviation.

between two regression lines. The first regression line has a slope and the second line is horizontal with minimal or no slope. In our experience this statistical model is best suited to objectively determine nutrient requirements provided multiple test intakes are studied ${ }^{(8-10)}$. The model also allows the calculation of $95 \%$ confidence intervals (CI), which provides a population safe requirement estimate. Our view is supported by other researchers especially in animal nutrition ${ }^{(11,12)}$, where determination of exact nutrient requirements has significant implications in optimizing feed costs.

\section{Amino acid requirements in adult humans}

\section{Indicator amino acid oxidation}

The IAAO technique is based on the concept that when one IDAA is deficient for protein synthesis, then all other amino acids including the indicator amino acid (another IDAA, usually L-[1-13C]phenylalanine) are in excess and are therefore oxidized ${ }^{(13)}$. This is primarily because excess amino acids cannot be stored and therefore must be partitioned between incorporation into protein or oxidation. With increasing intake of the limiting amino acid, oxidation of the indicator amino acid will decrease, reflecting increasing incorporation into protein ${ }^{(14)}$. Once the requirement is met for the limiting amino acid, there will be no further change in the oxidation of the indicator amino acid with increasing intake of the test amino acid (Fig. 1). The inflection point where the oxidation of the indicator amino acid stops decreasing and reaches a plateau is referred to as the 'breakpoint' (Fig. 2). The breakpoint, identified with the use of two-phase linear regression analysis, indicates the estimated average requirement (EAR) of the limiting (test) amino acid ${ }^{(8,13,15)}$. This minimally invasive IAAO method has been systematically applied to determine 
most IDAA requirements in adult humans (Table 1). The requirement values obtained using the IAAO method were used to derive amino acid intake recommendations in the recent $\mathrm{DRI}^{(1)}$ and $\mathrm{FAO}^{(2)}$ reports.

\section{Advantages of the indicator amino acid oxidation technique}

The IAAO method has several advantages in determining amino acid requirements when compared to the other available methods. The minimally invasive IAAO protocol involves 2 days adaptation to a fixed protein intake and study day adaptation to the test amino acid intake ${ }^{(16,17)}$. Each study day involves 8 hourly meals, with sampling of breath for measurement of ${ }^{13} \mathrm{CO}_{2}$ enrichment $\left(\mathrm{F}^{13} \mathrm{CO}_{2}\right)$, and urine for phenylalanine kinetics. This protocol has been validated for oral delivery of isotope ${ }^{(18)}$ and measurement of urinary isotopic enrichment to calculate amino acid kinetics ${ }^{(19)}$. The short-term adapted fed state IAAO model allows each subject to participate in multiple studies over a range of intakes (deficient to excess), and the amino acid requirements of each individual can be determined.

The breakpoint estimate of requirement is usually determined from the rate of oxidation $\left(\mathrm{F}^{13} \mathrm{CO}_{2}\right)$ of the labeled tracer (usually $1-{ }^{13} \mathrm{C}$-phenylalnine). This is one of the key strengths of the IAAO method; this variable represents an end point measurement which takes into account all losses and uses by the body. Recently, we showed in healthy young adults that the breakpoint for indicator amino acid oxidation measured using $\mathrm{F}^{13} \mathrm{CO}_{2}$ was very similar to the breakpoint for phenylalanine hydroxylation measured using apo B-100, a hepatic export protein which is synthesized from intrahepatocyte amino acids ${ }^{(20)}$; and thus represents the intracellular enrichment of phenylalanine at the site of protein synthesis in the liver. These data provide strong support for the initial observation by Ball and Bayley ${ }^{(21)}$ that phenylalanine oxidation was inversely related to change in liver protein synthesis. Amino acid oxidation measured using plasma enrichments may be in error, because plasma is not the true precursor pool from which protein synthesis takes place. Therefore, the use of $\mathrm{F}^{13} \mathrm{CO}_{2}$ circumvents the complex issue of measuring the true precursor pool enrichment in humans during routine studies where relative rates are being compared.

The choice of indicator amino acid is critical to sensitively partition the response to graded test intakes between protein synthesis or oxidation. The criteria for selecting the indicator amino acid are: a) it must be dietary indispensable amino acid; b) it must have a carboxyl-labeled carbon that is irreversibly oxidized upon catabolism and is released to $\mathrm{CO}_{2}$, which can be quantitatively measured in breath; and c) it must have a small, well regulated pool within the body and not be involved in significant pathways other than incorporation into protein or oxidation to $\mathrm{CO}_{2}$. Phenylalanine, in the presence of excess tyrosine, fits all three criteria ${ }^{(10)}$. Lysine and the branched-chain amino acids (BCAA) fulfill criteria a) and b), although lysine has a large pool in the body and BCAA, particularly leucine, have a variable pool ${ }^{(22)}$ and leucine has been shown to be involved in stimulating protein synthesis and insulin secretion ${ }^{(23)}$. During the initial development of the IAAO method in pigs, phenylalanine (in the presence of excess tyrosine) and lysine were shown to provide reliable estimates of tryptophan ${ }^{(24)}$ and protein $^{(21)}$ requirements. Most of the IAAO studies conducted in humans thus far have utilized L-1 $-{ }^{13} \mathrm{C}$-Phenylalanine in the presence of excess tyrosine as the indicator amino acid (Table 1). Leucine and lysine on the other hand have provided more variable breath $\mathrm{CO}_{2}$ data in studies to determine the phenylalanine requirements of humans ${ }^{(25,26)}$, and were found to be less suited as an indicator amino acid. In our opinion phenylalanine (in the presence of excess tyrosine) is the ideal indicator amino acid to determine amino acid and protein requirements.

One of the criticisms of the IAAO model has been that subjects are only adapted to the test amino acid intake on the study day. To examine whether additional days of adaptation are necessary to determine requirements using the IAAO method, Moehn et al. ${ }^{(27)}$ tested phenylalanine oxidation

Table 1. Dietary indispensable amino acid requirements in adult humans

\begin{tabular}{|c|c|c|c|c|c|}
\hline Amino Acid & $\begin{array}{c}\text { IAAO* Based } \\
\text { Requirement } \\
\text { Estimate }(\mathrm{mg} / \mathrm{kg} \text { per } \mathrm{d})\end{array}$ & $\begin{array}{c}\text { 24h-IAAO/IAAB† Based } \\
\text { Requirement Estimate }{ }^{2} \\
(\mathrm{mg} / \mathrm{kg} \text { per } \mathrm{d})\end{array}$ & $\begin{array}{r}\mathrm{FAO} \neq 1985^{(2)} \\
(\mathrm{mg} / \mathrm{kg} \text { per d) }\end{array}$ & $\begin{array}{l}\text { DRI§ } 2005^{(1)} \\
\text { (mg/kg per d) }\end{array}$ & $\begin{array}{c}\mathrm{FAO} / \mathrm{WHO} / \text { UNU } \ddagger 2007^{(2)} \\
(\mathrm{mg} / \mathrm{kg} \text { per d) }\end{array}$ \\
\hline Histidine & - & - & 8-12 & 11 & 10 \\
\hline Isoleucine & 42 & - & 10 & 15 & 20 \\
\hline Leucine & 55 & 40 & 14 & 34 & 39 \\
\hline Lysine & 37 & 31 & 12 & 31 & 30 \\
\hline Methionine (with no cysteine) & 13 & 15 & 13 & 15 & 15 \\
\hline Phenylalanine (with no tyrosine) & 48 & 38 & 14 & 27 & 25 \\
\hline Threonine & 19 & 15 & 7 & 16 & 15 \\
\hline Tryptophan & 4 & - & 3.5 & 4 & 4 \\
\hline Valine & 47 & 20 & 10 & 19 & 26 \\
\hline Total BCAA & 144 & - & - & - & - \\
\hline
\end{tabular}

* Indicator amino acid oxidation.

†24h-Indicator amino acid oxidation/Indicator amino acid balance.

$\ddagger$ Food and Agriculture Organization/World Health Organization/United Nations University.

$\S$ Dietary Reference Intakes.

I IAAO based requirements for isoleucine, leucine and valine are derived from total BCAA requirements and the BCAA proportion in egg protein. 
following various periods of adaptation to varying lysine and protein intakes in growing and adult pigs. Phenylalanine oxidation was not different following either 2 or $10 \mathrm{~d}$ of adaptation to lysine or protein intake. Furthermore, Elango et al. ${ }^{(28)}$ recently demonstrated that $\mathrm{L}-\left[1-{ }^{13} \mathrm{C}\right]$ phenylalanine oxidation, measured as $\mathrm{F}^{13} \mathrm{CO}_{2}$ which is the primary variable used for determination of the breakpoint, was not significantly different following $8 \mathrm{~h}$, $3 \mathrm{~d}$ or $7 \mathrm{~d}$ of adaptation to a wide range of lysine intakes in young men. Therefore, the minimally invasive model provides valid estimates of amino acid requirements to be determined in short periods of time and thus is highly suitable for application in vulnerable populations.

\section{4h-Indicator amino acid oxidation and balance (24h-IAAO and 24h-IAAB)}

Young, Kurpad and co-workers ${ }^{(29)}$ applied the IAAO method with modifications to include test amino acid intake adaptation for $6 \mathrm{~d}$ followed by measurement of an indicator amino acid oxidation (usually $1-{ }^{13} \mathrm{C}$-Leucine), during a $24 \mathrm{~h}$ period ( $12 \mathrm{~h}$ fasted and $12 \mathrm{hfed}$ ). This method, referred to as $24 \mathrm{~h}-\mathrm{IAAO}$, also allows the calculation of $24 \mathrm{~h}$-indicator amino acid balance (24h-IAAB), which is derived by subtracting leucine oxidation from leucine intake. This model uses intravenous isotope infusion for $24 \mathrm{~h}$ and involves collection of breath and blood samples for measurement of plasma enrichment of the isotope. The protocol is demanding and more invasive. Requirements have been estimated for lysine, threonine, methionine (with no cysteine), valine and phenylalanine in healthy well nourished Indians ${ }^{(30-34)}$ (Table 1). The $24 \mathrm{~h}-$ IAAO/IAAB model was also applied to chronically undernourished Indian men to identify lysine and methionine requirements. These elaborate and expensive studies have provided valuable information with respect to the application of amino acid requirement values globally because they were the first to show that the amino acid requirement values are similar in populations of developing countries and are comparable to estimates obtained in healthy subjects of the Western world.

\section{Comparison of requirement estimates for adult humans determined using IAAO and 24h-IAAO/IAAB methods}

Comparisons can be made of requirement estimates determined using IAAO and 24h-IAAO/IAAB methods for lysine, threonine, methionine (with no cysteine) and phenylalanine (with no tyrosine). The method used for the determination of amino acid requirements does not appear to have a systematic effect on the estimate of requirement (Table 2). The requirements for lysine and threonine determined by the IAAO method are higher than the requirements determined by the 24h-IAAO/IAAB method. Conversely, the requirement for methionine determined by the IAAO method is lower than the requirement derived by the 24h-IAAO/IAAB method. In all cases, the differences among the estimates are less than the typical measurement error.

The fundamental difference between the two methods has been the period of adaptation, and measurements during

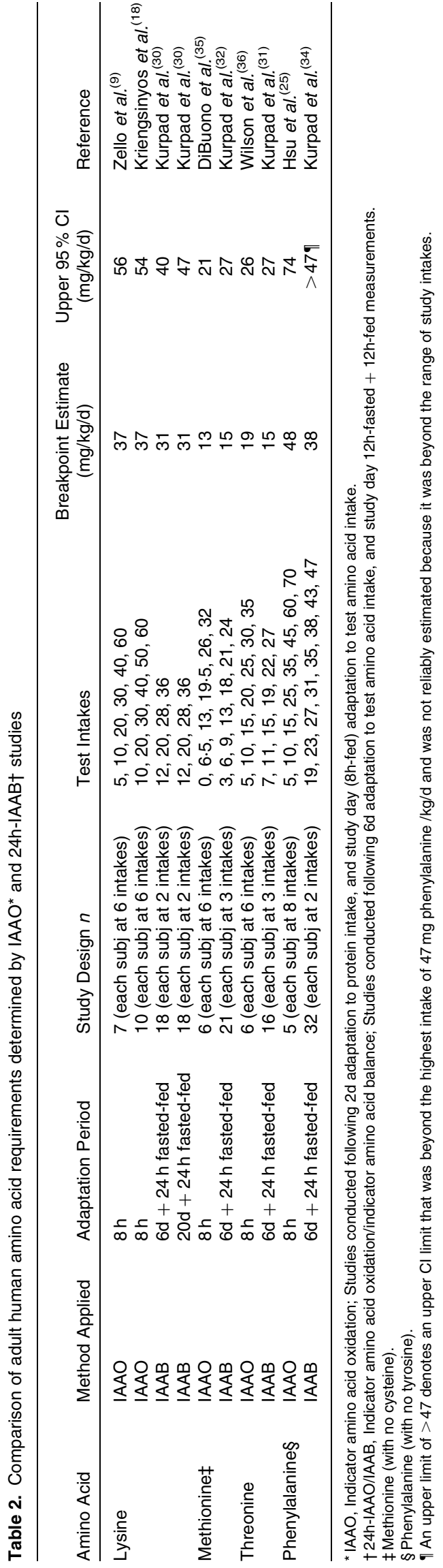


fed-fasted conditions. As described above, in growing pigs, adult pigs ${ }^{(27)}$ and adult humans ${ }^{(28)}$ it has been shown that a prior adaptation period to various lysine intakes did not influence the primary variable $\left(\mathrm{F}^{13} \mathrm{CO}_{2}\right)$ used to determine the IAAO response. With respect to measurements during fed and fasted conditions, there is evidence from the 24h-IAAO/IAAB studies that the requirements for threonine or lysine derived from $12 \mathrm{~h}$-fed and $24 \mathrm{~h}$ oxidation measurements do not differ ${ }^{(30,31)}$. Hence the measurements during the $12 \mathrm{~h}$ fasting period are not needed in order to define amino acid requirements, Virtually identical threonine requirements of $15 \mathrm{mg} / \mathrm{kg}$ per $\mathrm{d}$ and lysine requirements of $31 \mathrm{mg} / \mathrm{kg}$ per $\mathrm{d}$ are obtained by using either the $12 \mathrm{~h}$-fed IAAO measurements or 24h-IAAO/IAAB measurements.

The $24 \mathrm{~h} \mathrm{IAAO/IAAB}$ model is more demanding, time consuming and expensive to conduct than the fed state IAAO which only takes $8 \mathrm{~h}$. Presumably for this reason, the range of test amino acid intakes tends to be much narrower and closer to the expected breakpoint (Table 2). In the initial set of 24h-IAAO/IAAB studies the breakpoints were determined based on 4 test intakes (lysine requirements, refer Table 2). As detailed above in the section 'Methodological and data analysis considerations to determine amino acid and protein requirements', to confidently identify the breakpoint it is necessary to provide a range of test intakes well below and above the expected breakpoint. It can also be observed in most of the $24 \mathrm{~h}-\mathrm{IAAB}$ studies, that the upper $95 \% \mathrm{CI}$ (or population-safe) estimate either is a value that was not part of the included test intake, or could not be confidently identified (phenylalanine requirements). Furthermore not all subjects were studied at all levels of test amino acid intakes (Table 2). By comparison, the IAAO model is minimally invasive and relatively less demanding, more rapid and therefore allows multiple test intakes over a wide range from deficient to excess. Each subject is studied at all test intakes with the number of test intakes being 6-7, thereby allowing the determination of individual amino acid requirements, as well as a statistically stronger estimate of the requirement. For these reasons, as well as the advantages of the IAAO method detailed above, it has been possible to apply the IAAO model to determine amino acid requirements in children and in disease.

\section{Amino acid requirements in children}

Determination of amino acid requirements in children has traditionally been difficult because it is impractical and unethical to feed deficient amino acid intakes for prolonged periods of time. Therefore, current recommendations for amino acids in children are based on a factorial method. Development of the minimally invasive IAAO model enabled the direct determination of requirements for: total $\mathrm{BCAA}^{(37)}$, total sulphur amino acids (TSAA) ${ }^{(38)}$, methionine (with cysteine) ${ }^{(39)}$ and lysine ${ }^{(40)}$, in healthy school-age children $(6-11 y)$ (Table 3). Requirement estimates in children were similar to the estimates in adult humans, which suggests that the experimentally derived values predominantly reflect maintenance requirements, and may not take into account all the growth needs ${ }^{(15)}$. Children of this age group $(8-10 y)$ are much slower growing $(0.03 \% / \mathrm{d})$ when compared to children such as neonates or adolescents who grow more rapidly. For example using the same IAAO method the lysine requirement in parenterally fed neonates was determined to be $105 \mathrm{mg} / \mathrm{kg}$ per $\mathrm{d}^{(41)}$, compared to $35 \mathrm{mg} / \mathrm{kg}$ per $\mathrm{d}$ in adults and school aged children. During the IAAO $8 \mathrm{~h}$ study protocol in school aged children, the estimate of amino acid requirement does include the requirement for both maintenance and growth, but since the maintenance component is the predominant part of most indispensable amino acid requirements except during stages of rapid growth ${ }^{(1)}$ we predict that addition of the calculated growth component to the estimated EAR would ensure proper growth in rapidly growing children. The growth component is estimated from the rate of protein deposition for different age groups, the amino acid composition of whole body protein and the incremental efficiency of protein utilization ${ }^{(1)}$. The lysine required for growth in $8-10 y$ children is calculated as the product of rate of protein deposition $(49 \mathrm{mg} / \mathrm{kg} \text { per } \mathrm{d})^{(1)}$ and lysine composition of whole body $(0.073 \%)$ which is divided by 0.58 , the efficiency of dietary protein utilization to yield a value of $6 \cdot 1 \mathrm{mg} / \mathrm{kg}$ per $\mathrm{d}^{(40)}$ (Table 3 ).

We recently applied the IAAO method in healthy schoolaged children in India. The mean lysine requirement and the upper $95 \%$ confidence interval for Indian children were determined to be $33.5 \mathrm{mg} / \mathrm{kg}$ per $\mathrm{d}$ and $46.6 \mathrm{mg} / \mathrm{kg}$ per $\mathrm{d}$ respectively ${ }^{(42)}$. The mean lysine requirements of Indian children were almost identical to those of Canadian children $\left(35 \mathrm{mg} / \mathrm{kg}\right.$ per d) ${ }^{(40)}$ (Table 3). The Canadian children were $3 \cdot 2 \%$ and $17 \cdot 7 \%$ taller and heavier respectively, with a $1.5 \%$ greater body fat percentage than the Indian children, although their ages and IAAO study protocol were identical ${ }^{(40,42)}$. The similar lysine requirements resulting from these studies in two geographically and socio-economically distinct regions support the current global $\mathrm{FAO}^{(2)}$ lysine recommendation of $35 \mathrm{mg} / \mathrm{kg}$ per $\mathrm{d}$ for children aged $3-10 \mathrm{y}$. These results also suggest that there is no evidence of adaptation resulting in lower lysine requirements in the developing regions of the world such as India where a mainly cereal based diet limiting in lysine is consumed.

Table 3. Dietary indispensable amino acid requirements in healthy school-age children

\begin{tabular}{lcc}
\hline & $\begin{array}{c}\text { IAAO* Based } \\
\text { Requirement } \\
\text { Estimate (mg/kg per d) }\end{array}$ & DRI 2005(1) \\
Amino Acid & $147(157) \ddagger$ & 81 \\
\hline Total BCAA† & $12 \cdot 9(16) \ddagger$ & 18 \\
Methionine (with no cysteine) & $5 \cdot 8$ & - \\
Methionine (with cysteine) & $35(40) \ddagger$ & 37 \\
Lysine (Canadian children) & $33 \cdot 5$ & 37 \\
Lysine (Indian children) & & \\
\hline * IAAO, indicator amino acid oxidation. & \\
†Total BCAA, Branched chain amino acid (isoleucine + leucine + valine). \\
$\begin{array}{l}\text { † Requirement values within parentheses reflect addition of growth component to } \\
\text { experimentally determined value. }\end{array}$
\end{tabular}


Table 4. Amino acid requirements in children with Classic Phenylketonuria

\begin{tabular}{lcccl}
\hline Amino Acid & $\mathrm{mg} / \mathrm{kg}$ per d & Total Aromatic Amino Acid (\%) & Current Recommendation (\%) & Reference \\
\hline Tyrosine & 19 & 60 & 80 & Bross et al. $^{(43)}$ \\
Phenylalanine & 14 & 40 & 20 & Courtney-Martin et al. $^{(44)}$ \\
\hline
\end{tabular}

\section{Amino acid requirements in disease}

Dietary management of specific diseases requires knowledge of nutrient requirements in order to have a successful clinical outcome. Metabolic disorders such as phenyketonuria (PKU) require tyrosine supplementation with phenylalanine restriction, and maple syrup urine disease (MSUD) requires BCAA restriction. The minimally invasive IAAO model was used to determine tyrosine ${ }^{(43)}$ and phenylalanine ${ }^{(44)}$ requirements in children with classical PKU and the requirements were found to be 19 and $14 \mathrm{mg} / \mathrm{kg}$ per d, respectively (Table 4). These values suggest that the ratio of aromatic amino acids is 60 and $40 \%$ of tyrosine and phenylalanine, respectively, which is considerably different from the current recommendation of 80 and $20 \%$ for the management of patients with $\mathrm{PKU}^{(44)}$. Similarly, the mean total BCAA requirements in MSUD patients was determined to be $45 \mathrm{mg} / \mathrm{kg}$ per d, compared to the requirements of $144 \mathrm{mg} / \mathrm{kg}$ per $\mathrm{d}$ in healthy people $^{(45)}$ (Table 5).

Children with liver disease were thought to have increased BCAA requirements, based on measurements of plasma amino acid concentrations. We therefore applied the IAAO method using L- $\left[1-{ }^{13} \mathrm{C}\right]$ phenylalanine to determine total BCAA needs in children with cholestatic liver disease ${ }^{(46)}$. The mean requirement was determined to be $209 \mathrm{mg} / \mathrm{kg}$ per $\mathrm{d}$ which is $\sim 30 \%$ higher than the mean requirement estimate of $147 \mathrm{mg} / \mathrm{kg}$ per d determined earlier in healthy children ${ }^{(37)}$ (Table 5). Using a similar protocol, the mean total BCAA requirements in children post liver transplantation was determined to be $172 \mathrm{mg} / \mathrm{kg}$ per $\mathrm{d}^{(47)}$. Therefore, after liver transplantation BCAA requirements are lower than in children with liver disease, but higher than in healthy children. These IAAO derived requirement values are the first direct estimates of amino acid requirements in various disease states and disorders in children.

\section{Protein requirements in humans}

The current recommendations for protein requirements in adult humans are based on the recent $\mathrm{DRI}^{(1)}$ and $\mathrm{FAO}^{(2)}$ reports. The mean EAR and population-safe (RDA) recommendations for good quality protein were set at 0.66 and $0.8 \mathrm{~g} / \mathrm{kg} / \mathrm{d}$, respectively. These recommendations were based on a meta-analysis of nitrogen balance studies by Rand et $a l{ }^{(48)}$, in which protein requirements were estimated by fitting a linear regression analysis model to the data and measuring zero nitrogen balance as the criterion of nutritional adequacy. However, the physiological response relationship between nitrogen intake and balance is not linear due to a decreased efficiency of protein utilization as zero balance is approached $^{(49)}$. Because the physiological response relationship is curvilinear, a two-phase linear regression model ${ }^{(8)}$ or a smooth non-linear model ${ }^{(50)}$ has been proposed to be a more realistic biological analysis to determine protein requirements. The latter two models were however not adopted in the current DRI and FAO report because it was perceived that more data points on each individual were needed than were available in published studies. Also, in spite of the various limitations known, nitrogen balance remains the primary method for identifying protein needs, mainly because there has been no validated or accepted alternative method; there is a real need for a valid alternative method to assess protein requirements.

\section{Re-analysis of nitrogen balance studies}

Rand et al. ${ }^{(48)}$ conducted a thorough and careful meta-analysis of published nitrogen balance studies to suggest protein intake recommendations. The analysis included 19 studies in which subjects were tested at 3 intakes for periods of $10-14 \mathrm{~d}$, with urinary and faecal nitrogen collection during the final five days. The selected studies had test intakes around the expected requirements. Linear regression analysis was utilized to identify the intercept at zero balance, although the authors acknowledged that the nitrogen intake response curve is not linear ${ }^{(48)}$

Biologically, higher intakes of protein in adults do not result in further protein accretion. Therefore at some point the slope of nitrogen balance versus protein intake must equal zero, further supporting the idea that simple linear regression analysis is not appropriate. We applied two-phase linear regression cross-over analysis to 28 nitrogen balance studies $^{(51)}$ including the 19 studies used by Rand et al. ${ }^{(48)}$ for estimation of the current EAR and RDA using linear regression analysis. Our re-analysis included studies in which subjects were fed intakes above the expected requirements, which allowed us to partition the data for two-phase linear regression analysis (one line with ascending slope, and one line with minimal or no slope). Application of the two-phase linear regression model to the nitrogen balance data from 28 studies resulted in the estimation of a break point (mean, EAR)

Table 5. Branched-chain amino acid (BCAA) requirements in children with disease

\begin{tabular}{lcl}
\hline & $\begin{array}{c}\text { Total BCAA* } \\
\text { Requirement }^{*}\end{array}$ & \\
Physiological condition & 147 & Reference \\
\hline Healthy children & 45 & Mager et al. ${ }^{(37)}$ \\
MSUD† & 209 & Riazi et al. ${ }^{(45)}$ \\
Cholestatic liver disease & 172 & Mager et al. \\
Post liver transplantation & Mager et al. & \\
\hline
\end{tabular}

*Total BCAA, Branched chain amino acid (isoleucine + leucine + valine). †MSUD, maple syrup urine disease. 
Table 6. Protein requirements in humans

\begin{tabular}{|c|c|c|c|c|}
\hline & $\begin{array}{c}\mathrm{DRI}^{*} 2005^{(1)} / \mathrm{FAO}+2007^{(2)} \\
(\mathrm{g} / \mathrm{kg} \text { per d })\end{array}$ & $\begin{array}{c}\text { N Balance } \\
\text { (re-analyzed }) \ddagger^{(51)} \\
(\mathrm{g} / \mathrm{kg} \text { per d })\end{array}$ & $\begin{array}{l}\text { IAAO§ Adults }{ }^{(51)} \\
(\mathrm{g} / \mathrm{kg} \text { per d })\end{array}$ & $\begin{array}{l}\text { IAAO§ Children }{ }^{(52)} \\
(\mathrm{g} / \mathrm{kg} \text { per } \mathrm{d})\end{array}$ \\
\hline Estimated Average Requirement (EAR) & 0.66 & 0.91 & 0.93 & $1 \cdot 3$ \\
\hline Recommended Dietary Allowance (RDA) & 0.83 & 0.99 & $1 \cdot 2$ & 1.55 \\
\hline
\end{tabular}

*DRI, Dietary Reference Intakes.

†FAO, Food and Agricultural Organization.

$\ddagger$ Reanalysis of existing nitrogen balance studies using two-phase linear regression analysis. $\S I A A O$, indicator amino acid oxidation.

of $0.91 \mathrm{~g} / \mathrm{kg} / \mathrm{d}$ protein and an upper $95 \%$ confidence interval (population-safe, equivalent to RDA) of $0.99 \mathrm{~g} / \mathrm{kg} / \mathrm{d}^{(51)}$ (Table 6). These values are significantly higher than the current mean and population safe protein recommendations of 0.66 and $0.8 \mathrm{~g} / \mathrm{kg} / \mathrm{d}^{(1)}$

\section{Application of IAAO to determine protein requirements}

The above described re-analysis of balance data highlighted the need to develop and validate alternative methods to determine protein requirements. Ball and Bayley ${ }^{(21)}$ were the first to demonstrate, in growing pigs, that the indicator amino acid oxidation (IAAO) method could be used to determine protein requirements. Their results were not different from protein requirement estimates determined by growth experiments. Due to the various advantages of the IAAO method as described above we examined the total protein requirement in adult humans using the IAAO method ${ }^{(51)}$. Eight young adult subjects participated in seven studies each, in which they received graded intakes of protein ranging from $0 \cdot 1$ to $1.8 \mathrm{~g} / \mathrm{kg} / \mathrm{d}$, and indicator amino acid ( $\mathrm{L}-\left[1-{ }^{13} \mathrm{C}\right]$ phenylalanine) oxidation was measured on each day. The diets provided energy at $1.5 \times$ resting energy expenditure, with $33 \%$ of energy from fat, and variable energy from carbohydrate (48-66\%) and protein (1-19\%), based on the amino acid composition of egg protein. The intake of phenylalanine (indicator amino acid) was maintained constant, with excess tyrosine, to ensure that with increasing intakes of total protein nitrogen the indicator amino acid was partitioned between oxidation and protein synthesis. With increasing protein intakes, oxidation of phenylalanine decreased until a breakpoint was reached (between an intake of 0.9 and $1.2 \mathrm{~g} / \mathrm{kg} / \mathrm{d}$ ). There was no further decrease in phenylalanine oxidation with increasing protein intake, suggesting no further incorporation of the indicator amino acid into protein. Application of the two-phase linear regression analysis to the data identified a breakpoint (mean requirement) and the upper 95\% CI, population-safe requirement. The mean and population safe requirements were determined to be 0.93 and $1.2 \mathrm{~g} / \mathrm{kg} / \mathrm{d}$ and are $41 \%$ and $50 \%$, respectively higher than the current DRI recommendations (Table 6). The IAAO based protein requirement values and the re-analysis of preexisting nitrogen balance studies using two-phase linear regression analysis support each other ${ }^{(51)}$. Most recently, the IAAO method has been used to determine protein requirements in $6-10 \mathrm{y}$ old children and the mean and safe protein requirements were determined to be 1.3 and $1.55 \mathrm{~g} / \mathrm{kg} / \mathrm{d}$, respectively ${ }^{(52)}$. The current $\mathrm{DRI}^{(1)}$ and $\mathrm{FAO}^{(2)}$ recommendations are set at 0.76 and $0.85 \mathrm{~g} / \mathrm{kg} / \mathrm{d}$. The new values are significantly higher than current recommendations and therefore there is an urgent need to re-assess recommendations for protein intake in humans.

\section{Summary}

In conclusion, the IAAO method is a robust, rapid and reliable method to determine amino acid requirements in different species $^{(9,14,21)}$, across the life cycle ${ }^{(18,40,41)}$ and in disease ${ }^{(43-47)}$. Theoretically the $24 \mathrm{~h}-\mathrm{IAAB}$ model is considered to be better suited to determine amino acid requirements ${ }^{(1,2)}$, although from a practical aspect the IAAO method is far better suited. Furthermore, the IAAO and 24h-IAAB methods provide similar requirement estimates for the amino acids, lysine, threonine, methionine and phenylalanine, for which both methods have been applied, and there does not appear to be a systematic bias due to the choice of method. Due to the minimal invasive nature of the IAAO method it is now possible to determine amino acid and protein requirements in other vulnerable populations, including pregnant and lactating women, and the elderly. The recent adaptation of the IAAO method to determine protein requirements in adult humans and children is novel. The results suggest that current mean protein intake recommendations in adults $(0.66 \mathrm{~g} / \mathrm{kg} / \mathrm{d})$ and children $(0.76 \mathrm{~g} / \mathrm{kg} / \mathrm{d})$ are significantly underestimated compared to the IAAO method based requirement of $0.93 \mathrm{~g} / \mathrm{kg} /$ $\mathrm{d}^{(51)}$ and $1.3 \mathrm{~g} / \mathrm{kg} / \mathrm{d}^{(52)}$, respectively. These results have critical significance for populations living in developing countries.

\section{Acknowledgements}

The authors have no conflicts of interest. All authors contributed to the preparation of the manuscript. Supported by the Canadian Institutes for Health Research (grant \# MOP 10321 and FRN 12928).

\section{References}

1. Dietary Reference Intakes (2005) Institute of Medicine, Food and Nutrition Board, Dietary Reference Intakes: Energy, Carbohydrate, Fiber, fat, Fatty Acids, Cholesterol, Protein and Amino Acids. Washington, DC: The National Academy Press. 
2. Food and Agricultural Organization (2007) Protein and amino acid requirements in buman nutrition. Report of a joint WHO/FAO/UNU expert consultation. WHO Technical Report Series, No. 935. Geneva, Switzerland.

3. Rand WM, Young VR \& Scrimshaw NS (1976) Change of urinary nitrogen excretion in response to low-protein diets in adults. Am J Clin Nutr 29, 639-644.

4. Fuller MF \& Garlick PJ (1994) Human amino acid requirements: can the controversy be resolved? Annu Rev Nutr 14, 217-241.

5. Young VR \& El-Khoury AE (1996) Human amino acid requirements: a re-evaluation. Food Nutr Bull 17, 191-203.

6. Millward DJ (1998) Metabolic demands for amino acids and the human dietary requirement: Millward and Rivers (1988) revisited. J Nutr 128, 2563S-2576S.

7. Young VR \& Borgonha S (2000) Nitrogen and amino acid requirements: the Massachusetts Institute of Technology amino acid requirement pattern. J Nutr 130, 1841S-1849S.

8. Pencharz PB \& Ball RO (2003) Different approaches to define individual amino acid requirements. Annu Rev Nutr 23, 101-116.

9. Zello GA, Pencharz PB \& Ball RO (1993) Dietary lysine requirement of young adult males determined by oxidation of L-[1-13C]phenylalanine. Am J Physiol 264, E677-E685.

10. Zello GA, Wykes LJ, Ball RO \& Pencharz PB (1995) Recent advances in methods of assessing dietary amino acid requirements for adult humans. J Nutr 125, 2907-2915.

11. Lamberson WR \& Firman JD (2002) A comparison of quadratic versus segmented regression procedures for estimating nutrient requirements. Poult Sci 81, 481-484.

12. Robbins KR, Saxton AM \& Southern LL (2006) Estimation of nutrient requirements using broken-line regression analysis. J Anim Sci 84, E155-E165.

13. Elango R, Ball RO \& Pencharz PB (2008) Indicator amino acid oxidation: concept and application. J Nutr 138, 243-246.

14. Kim KI, McMillan I \& Bayley HS (1983) Determination of amino acid requirements of young pigs using an indicator amino acid. Br J Nutr 50, 369-382.

15. Elango R, Ball RO \& Pencharz PB (2008) Individual amino acid requirements in humans: an update. Curr Opin Clin Nutr Metab Care 11, 34-39.

16. Thorpe JM, Roberts SA, Ball RO, et al. (1999) Prior protein intake may affect phenylalanine kinetics measured in healthy adult volunteers consuming $1 \mathrm{~g}$ protein. kg-1. d-1. J Nutr 129, 343-348.

17. Bross R, Ball RO \& Pencharz PB (1998) Development of a minimally invasive protocol for the determination of phenylalanine and lysine kinetics in humans during the fed state. J Nutr 128, 1913-1919.

18. Kriengsinyos W, Wykes LJ, Ball RO, et al. (2002) Oral and intravenous tracer protocols of the indicator amino acid oxidation method provide the same estimate of the lysine requirement in healthy men. J Nutr 132, 2251-2257.

19. Wykes LJ, Ball RO, Menendez CE, et al. (1990) Urine collection as an alternative to blood sampling: a noninvasive means of determining isotopic enrichment to study amino acid flux in neonates. Eur J Clin Nutr 44, 605-608.

20. Raffi M, McKenzie JM, Roberts SA, et al. (2008) In vivo regulation of phenylalanine hydroxylation to tyrosine, studied using enrichment in apoB-100. Am $J$ Physiol 294, E475-E479.

21. Ball RO \& Bayley HS (1986) Influence of dietary protein concentration on the oxidation of phenylalanine by the young pig. BrJ Nutr 55, 651-658.
22. Waterlow JC (2006) Protein Turnover. pp. 20-63. Oxfordshire, UK: CABI Publishing.

23. Kimball SR \& Jefferson LS (2006) Signaling pathways and molecular mechanisms through which branched-chain amino acids mediate translational control of protein synthesis. J Nutr 136, 227S-231S.

24. Ball RO \& Bayley HS (1984) Tryptophan requirement of the $2 \cdot 5-\mathrm{kg}$ piglet determined by the oxidation of an indicator amino acid. $J$ Nutr 114, 1741-1746.

25. Hsu JW, Goonewardene LA, Raffi M, et al. (2006) Aromatic amino acid requirements in healthy men measured by indicator amino acid oxidation. Am J Clin Nutr 83, 82-88.

26. Hsu JW, Kriengsinyos W, Wykes LJ, et al. (2006) Leucine is not a good choice as an indicator amino acid for determining amino acid requirements in men. J Nutr 136, 958-964.

27. Moehn S, Bertolo RF, Pencharz PB, et al. (2004) Indicator amino acid oxidation responds rapidly to changes in lysine or protein intake in growing and adult pigs. J Nutr $\mathbf{1 3 4}$ $836-841$.

28. Elango R, Humayun MA, Ball RO, et al. (2009) Indicator amino acid oxidation is not affected by period of adaptation to a wide range of lysine intake in healthy young men. $J$ Nutr 139, 1082-1087.

29. Kurpad AV, Raj T, El-Khoury A, et al. (2001) Lysine requirements of healthy adult Indian subjects, measured by an indicator amino acid balance technique. Am J Clin Nutr 73, 900-907.

30. Kurpad AV, Regan MM, Raj T, et al. (2002) Lysine requirements of healthy adult Indian subjects receiving long-term feeding, measured with a 24-h indicator amino acid oxidation and balance technique. Am J Clin Nutr 76, 404-412.

31. Kurpad AV, Raj T, Regan MM, et al. (2002) Threonine requirements of healthy Indian men, measured by a $24-\mathrm{h}$ indicator amino acid oxidation and balance technique. $\mathrm{Am}$ J Clin Nutr 76, 789-797.

32. Kurpad AV, Regan MM, Varalakshmi S, et al. (2003) Daily methionine requirements of healthy Indian men, measured by a 24-h indicator amino acid oxidation and balance technique. Am J Clin Nutr 77, 1198-1205.

33. Kurpad AV, Regan MM, Raj TD, et al. (2005) The daily valine requirement of healthy adult Indians determined by the 24-h indicator amino acid balance approach. Am J Clin Nutr 82, 373-379.

34. Kurpad AV, Regan MM, Raj TD, et al. (2006) The daily phenylalanine requirement of healthy Indian adults. $\mathrm{Am} \mathrm{J}$ Clin Nutr 83, 1331-1336.

35. Di Buono M, Wykes LJ, Ball RO, et al. (2001) Total sulfur amino acid requirement in young men as determined by indicator amino acid oxidation with L-[1-13C]phenylalanine. Am J Clin Nutr 74, 756-760.

36. Wilson D, Rafii M, Ball RO, et al. (2000) Threonine Requirement in young adult men determined by indicator amino acid oxidation, using L-[13C]-phenylalanine. Am J Clin Nutr 71, 757-764.

37. Mager DR, Wykes LJ, Ball RO, et al. (2003) Branched-chain amino acid requirements in school-aged children determined by indicator amino acid oxidation (IAAO). J Nutr 133, 3540-3545.

38. Turner JM, Humayun MA, Elango R, et al. (2006) Total sulfur amino acid requirement of healthy school-aged children as determined by indicator amino acid oxidation technique. Am J Clin Nutr 83, 619-623.

39. Humayun MA, Turner JM, Elango R, et al. (2006) Minimum methionine requirement and cysteine sparing of methionine in healthy school-age children. Am J Clin Nutr 84, $1080-1085$. 
40. Elango R, Humayun MA, Ball RO, et al. (2007) Lysine requirement of healthy school-age children determined by the indicator amino acid oxidation method. Am J Clin Nutr 86, 360-366.

41. Chapman KP, Courtney-Martin G, Moore AM, et al. (2010) Lysine requirement in parenterally fed postsurgical human neonates. Am J Clin Nutr 91, 958-965.

42. Pillai R, Elango R, Muthayya S, et al. (2010) Lysine requirement of healthy, school-aged Indian children determined by the indicator amino acid oxidation technique. $J$ Nutr 140, 54-59.

43. Bross R, Ball RO, Clarke JT, et al. (2000) Tyrosine requirements in children with classical PKU determined by indicator amino acid oxidation. Am J Physiol Endocrinol Metab 278, E195-E201.

44. Courtney-Martin G, Bross R, Raffi M, et al. (2002) Phenylalanine requirement in children with classical PKU determined by indicator amino acid oxidation. Am J Physiol Endocrinol Metab 283, E1249-E1256.

45. Riazi R, Raffi M, Clarke JT, et al. (2004) Total branched-chain amino acids requirement in patients with maple syrup urine disease by use of indicator amino acid oxidation with L-[1-13C]phenylalanine. Am J Physiol Endocrinol Metab 287, E142-E149.
46. Mager DR, Wykes LJ, Roberts EA, et al. (2006) Branchedchain amino acid needs in children with mild-to-moderate chronic cholestatic liver disease. J Nutr 136, 133-139.

47. Mager DR, Wykes LJ, Roberts EA, et al. (2006) Effect of orthotopic liver transplantation (OLT) on branched-chain amino acid requirement. Pediatr Res 59, 829-834.

48. Rand WM, Pellett PL \& Young VR (2003) Meta-analysis of nitrogen balance studies for estimating protein requirements in healthy adults. Am J Clin Nutr 77, 109-127.

49. Young VR, Taylor YS, Rand WM, et al. (1973) Protein requirements of man: efficiency of egg protein utilization at maintenance and submaintenance levels in young men. J Nutr 103, 1164-1174.

50. Rand WM \& Young VR (1999) Statistical analysis of nitrogen balance data with reference to the lysine requirements in adults. J Nutr 129, 1920-1926.

51. Humayun MA, Elango R, Ball RO, et al. (2007) Reevaluation of the protein requirement in young men with the indicator amino acid oxidation technique. Am J Clin Nutr 86, 995-1002.

52. Elango R, Humayun MA, Ball RO, et al. (2011) Protein requirement of healthy school-age children determined by the indicator amino acid oxidation method. Am J Clin Nutr 94, 1545-1552. 